\title{
AMENDMENTS
}

\section{Author Correction: Microwave plasmonic mixer in a transparent fibre-wireless link}

Y. Salamin (D), B. Baeuerle, W. Heni (1), F. C. Abrecht, A. Josten (D), Y. Fedoryshyn, C. Haffner, R. Bonjour, T. Watanabe, M. Burla, D. L. Elder (D), L. R. Dalton and J. Leuthold (D)

Correction to: Nature Photonics https://doi.org/10.1038/s41566-018-0281-6, published online 29 October 2018.

In the version of this Letter originally published online, the ORCID number, 0000-0002-8900-3237, of the author A. Josten was missing; and in Fig. $2 \mathrm{~b}$, in the $y$ axis label, ' $\times 10^{5}$ should have been ' $\times 10^{3}$ '. These errors have now been corrected in all versions. 